\title{
MODIFYING EFFECTS OF INACTIVATED BOVINE SERUM ON THE ACUTE TOXICITY OF METHYLMERCURIC CHLORIDE IN CELLS CULTURED IN VITRO
}

\author{
Eiichi Kano†, Junji Miyakoshi†, Tomoko Kajimoto $\dagger$, Junko Matsumoto $\dagger$, \\ Junko Konda $\dagger$, Shoji Iwata $\dagger$, Makoto IKEBUCHi $\dagger$ \\ and Shun-ichi HoRIGuCHI††
}

培養細胞に打ける塩化メチル水銀急性毒性の

非㗢化血清による減弱効果

加 納 永 一*, 宮 越 順 二*, 梶本 智 子*, 松 本 順 子*,
誉 田 順 子*, 岩 田 庄 司*, 池 判 誠*, 堀口 俊 -**

\begin{abstract}
Dynamics of the killing of Ehrlich's murine ascites tumor cells by methylmercuric chloride, MMC, were investigated. Thresholds in the killing action of MMC were observed in the MMC treatment concentration, but not in the MMC treatment time. Inactivated bovine serum protected the E-cells from killing by MMC in vitro. The apparent MMC toxicity was reduced as the serum concentration increased, but remaining partially at high concentrations. Thus the serum increases the threshold for MMC toxicity. It was cofirmed that the mode of action, observed as the kinetics of the acute lethality by suspicious substances, could be examined promptly on the mammalian cell level by the present experimental system.
\end{abstract}

\section{INTRODUCTION}

Problems in toxicology and epidemiology of methylmercuric compounds are (1) whether or not the late effect from low doses of methylmercuric compounds is observed, (2) whether or not the linearity is observed between the exposed dose of methylmercuric compounds and the resultant genetic risks, (3) why the apparent toxic effect is higher in the nervous cells, and (4) whether or not the concept of maximum permissible dose in the food chain mainly from fish can be established. ${ }^{1)}$ To

$\uparrow$ Department of Radiation Biology, School of Pharmacy, Kyoto College of Pharmacy

t† Department of Preventive Medicine and Public Health, School of Medicine, Osaka City University Received for publication, June 28, 1976

* 京都薬科大学生物学教室

** 大阪市立大学医学部衛生学公衆衛生学教室 昭和51年 6 月 28 日受付 elucidate the above, a series of assays on the cell level is required. The approaches to the problems in toxic effects of methylmercuric compounds hitherto reported are (1) the mitotic inhibitions owing to the inactivation of the spindle fibers, ${ }^{2)}$ (2) disturbances in the cell division in the primary culture of human lymphocytes, ${ }^{8)}$ (3) mutagenic effect existing to some extent, ${ }^{4-6)}$ and (4) mitotic delay, cell killing, suppressed uptakes of ${ }^{3} \mathrm{H}$-thymidine and ${ }^{8} \mathrm{H}$-uridine, and DNA single strand scissions demonstrated in the cultured mouse leukemic L5178Y cells. ${ }^{7)}$

Among the cell level assays, analytic experiments for the mode of action by the cell survival kinetics is not yet ample. In the present communication, the observed survival profiles of the cultured Ehrlich's ascites tumor cells in vitro after the variety of the treatment conditions of methylmercuric chloride, abbreviated as MMC, and the modification of 
the cellular lethality of MMC by the concomitant treatment with inactivated bovine serum are shown. And the possible mode of action to the cells is discussed.

\section{MATERIALS AND METHODS}

\section{1) Cells}

Ehrlich's murine ascites tumor cells, abbreviated as E-cells and registered as JTC-11 cell line in Japan, were colonially cloned and utilized throughout the present series of experiments in vitro.

\section{2) Culture media}

One litre of the growth medium utilized, abbreviated as MLN-15, contains $730 \mathrm{ml}$ of Eagle's MEM solution, $100 \mathrm{ml}$ of NCTC-109 solution, $150 \mathrm{ml}$ of inactivated bovine serum and $20 \mathrm{ml}$ of lactalbumin hydrolysate solution, abbreviated as $\mathrm{LH}$. The $\mathrm{LH}$ solution was prepared by autoclaving $25 \mathrm{~g}$ of $\mathrm{LH}$ powder suspension in $1 l$ of Dulbecco's solution. All the solutions were filtered together except the serum which was filtered separately and was added afterwards. The numerals in succession after MLN shown below indicate the serum volume percentages.

3) Methylmercuric chloride, $M M C$, treatment

The original MMC solution in ethanol, $1 \mathrm{mg}$ $\mathrm{CH}_{3} \mathrm{HgCl}$ in $1 \mathrm{ml}$, prepared and ampouled by Tokyo Kasei Kogyo Co. Ltd., was diluted serially in the twice distilled water down to ten times to obtain the final concentration. One millilitre of MMC diluted thus, $10 \times$, was added into the cell-proliferating glass plates, which had been refed with $9 \mathrm{ml}$ of fresh MLN15, MLN- 0 or MLN-'s containing variety of serum volume percentages as scheduled prior to the MMC treatment. The plates under the treatment with MMC were incubated for the scheduled periods of time.

\section{4) Culture conditions}

(a) The cells were seeded in the proper numbers per glass plate for yielding the pertinent number of colonies as the surviving fractions. About a hundred surviving colonies for the plate, $6 \mathrm{~cm}$ in diameter, were suitable for the present culture system. (b) The plates were incubated over-night in the water saturated air of $5 \% \mathrm{CO}_{2}$ at $37^{\circ} \mathrm{C}$. (c) The control cell growth was followed during the experiment on successive days after plating. (d) The cells were treated with MMC at various concentrations for variously scheduled periods of time. (e) The MMC treatment medium was then sucked out. The plates were rinsed twice with MEM solution and then fed with $12 \mathrm{ml}$ of MLN-15. (f) The plates after the treatment were placed in the $\mathrm{CO}_{2}$ incubator and observed for colony formation.

\section{5) Criterion}

The survival fraction for every treatment group was estimated from number of colonies of seeded cells and the survival curves were analysed.

\section{RESULTS}

\section{Relationships of methylmercuric chloride} treatment time vs. survival

Exponentially growing E-cells were treated with $\mathrm{MMC}$ in a variety of the concentrations for the scheduled periods within $6 \mathrm{hr}$ at $37^{\circ} \mathrm{C}$. In one part of the experiments the medium, MLN-15, at the MMC treatment contained 15 volume percent of serum, while in the other, the medium, MLN-0, did not contain serum.

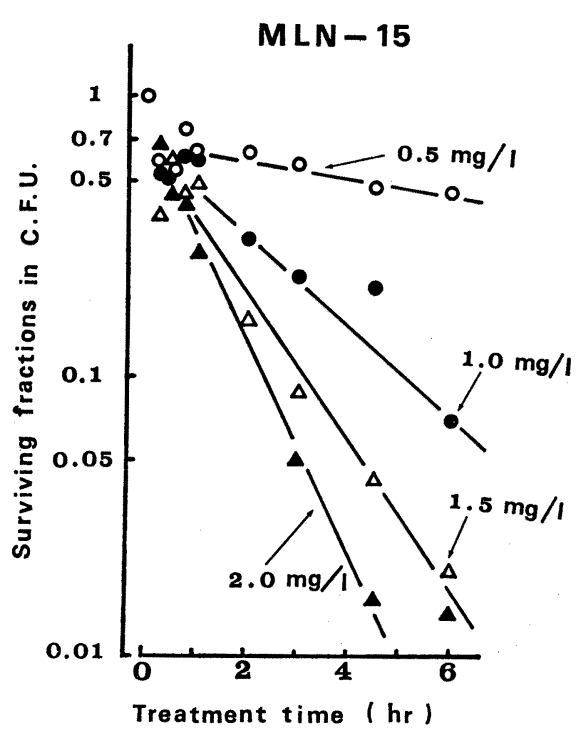

Fig. 1. Treatment time-survival curves in a variety of $\mathrm{CH}_{3} \mathrm{HgCl}$ concentrations. Ordinate: $\log$ surviving fractions in colony forming unit, C.F.U. Abscissa: hours of treatment time in MLN-15. The treatment medium contains $15 \%$ (v/v) of inactivated bovine serum. 
Table 1. Reciprocals of slopes and extrapolation numbers on $\mathrm{CH}_{3} \mathrm{HgCl}$ treatment time-survival curves of exponential Ehrlich's cells.

\begin{tabular}{clcccccc}
\hline \multirow{2}{*}{ Media } & \multicolumn{7}{c}{ Concentrations of $\mathrm{CH}_{3} \mathrm{HgCl}(\mathrm{mg} / \mathrm{l})$} \\
\cline { 2 - 7 } & & 0.005 & 0.05 & 0.5 & 1.0 & 1.5 & \multicolumn{1}{c}{2.0} \\
\hline \multirow{2}{*}{ MLN-0 } & $T_{0}(1 / \mathrm{K})$ & $\infty$ & $52 \mathrm{~min}$ & $19 \mathrm{~min}$ & & & $8.3 \mathrm{~min}$ \\
& $N$ & 1 & 1 & 1 & & & 1 \\
MLN-15 & $T_{0}(1 / \mathrm{K})$ & & & $14 \mathrm{hr}$ & $2.7 \mathrm{hr}$ & $1.6 \mathrm{hr}$ & $1.1 \mathrm{hr}$ \\
& $N$ & & & 0.7 & 0.7 & 0.7 & 0.7 \\
\hline
\end{tabular}

$T_{0}$ : the reciprocal of the slope in the straight portion of the curve indicates the treatment time required for the survival fraction to be reduced to the $1 / e$ or $37 \% . N$ : the extrapolation number on the logarithmic ordinate axis.

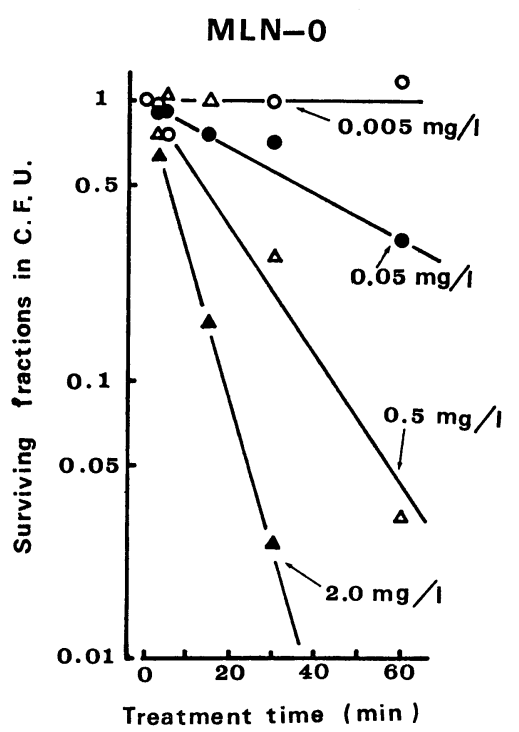

Fig. 2. Treatment time-survival curves in a variety of $\mathrm{CH}_{3} \mathrm{HgCl}$ concentrations. Ordinate: log surviving fractions in colony forming unit, C.F.U. Abscissa: hours of treatment time in MLN-0. The treatment medium contains no serum.

MMC treatment time-survival curves, in the conditions for the serum content, are shown in Figs. 1 and 2. The coefficients were estimated and summarized in Table 1 . Here $T_{0}$, the reciprocal of the slope in the straight portion of the curve, indicates the treatment time required for the survival fraction to be reduced to $1 / e, 37 \%$. $N$ indicates the extrapolation number on the logarithmic ordinate axis, towards which the straight portion of the curve is extrapolated.

2. Effects of inactivated bovine serum con-

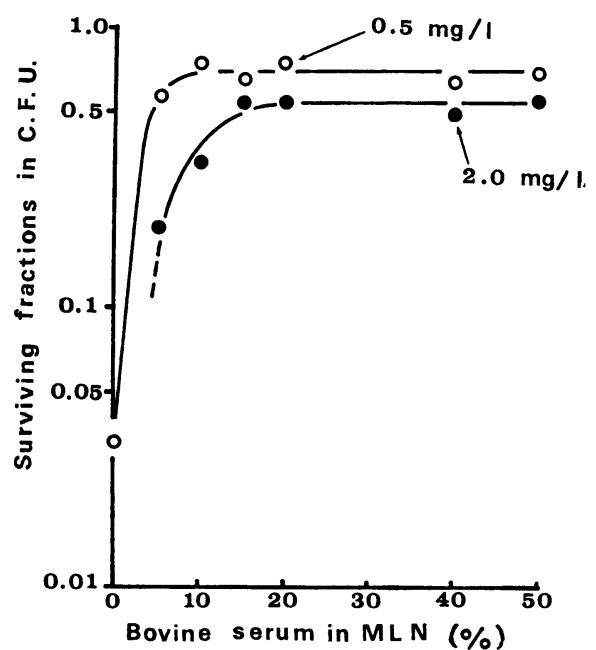

Fig. 3. Effects of bovine serum concentrations: through $\mathrm{CH}_{3} \mathrm{HgCl}$ treatment time, $60 \mathrm{~min}$, on the survivals. Ordinate: $\log$ surviving fractions in colony forming unit, C.F.U. Abscissa : the volume percentage of bovine serum in treatment media MLN-'s.

centrations during the time of treatment with $M M C$ on the cell survival

The effect was assayed in two MMC treatment conditions, i.e. $0.5 \mathrm{mg} / l$ for $60 \mathrm{~min}$ and $2.0 \mathrm{mg} / l$ for $60 \mathrm{~min}$, in which the bovine serum concentrations were varied from 0 to 50 volume percentages as shown in Fig. 3. Regardless the variety of the bovine serum concentrations as ranged from 15 to 50 volume percentages in MMC treatment medium, a constant survival fraction was given. On the other hand, where the treatment medium contained less than 15 volume percent of the bovine serum, the survival fractions from a. 
given MMC treatment condition except that for the serum, were reduced in relation to the reduction of the bovine serum concentration.

\section{DISCUSSION}

Present series of experiments indicates the action of methylmercuric chloride on the cell survival kinetics as follows:

(1) Relationship of MMC treatment time and survival was shown as a so-called onehit type curve $^{8)}$ in the serum-less treatment medium, MLN-0.

(2) The slopes of the one-hit type curves varied in relation to the treatment concentrations of MMC in MLN-0.

(3) Relationship of MMC treatment time and survival in the treatment medium MLN15 , containing 15 volume percent of the serum, showed upward concavity followed by a straight portion of the regression curve or, in other words, a biphasic regression curve.

(4) In the treatment in MLN-15, slopes of the strait portions also varied according to the MMC concentrations, which were remarkably gentler in comparison with those in MLN-0.

(5) Survivals from the given treatment conditions of MMC concentration and treatment time, except the condition of the serum, were reduced as the serum concentrations in the treatment medium were reduced from $15 \%$, while the survival remained constant as the serum concentrations were varied from 15 to $50 \%$.

(6) The reduction of the survivals in relation to that of the serum concentrations was observed more remarkably in the treatment with MMC concentration at $2.0 \mathrm{mg} / l$, than at $0.5 \mathrm{mg} / \mathrm{l}$.

No appreciable threshold of the MMC treatment time for the cell killing was shown in MLN-0 and MLN-15 both. It seems that MMC might randomly bind to cells, the expected frequency of the binding per unit period of time might be constant when the MMC reservoir in the medium was infinite and the concentration was given, and the number of the binding events might be accumulated in proportion to the treatment time when the cells were treated in the condition where the free, or the practically effective form of, MMC would not be inactivated frequently in the culture medium, e.g. in MLN-0. It would be also considered that the probability, with which the cells were bound with the enough number of $\mathrm{MMC}$ molecules for cell killing, increased in relation to the increment of the treatment period of time.

However, the apparent cell killing threshold was shown for MMC treatment concentration. It was $0.005 \mathrm{mg} / l$ or between 0.005 and 0.05 $\mathrm{mg} / l$, so far as assayed for $1 \mathrm{hr}$ treatment time or less in MLN-0. The threshold seems to exist on the treatment in MLN-15 also, which should be less than $0.5 \mathrm{mg} / l$.

It was indicated by the extrapolation number of less than unity that the MMC treatment time-survival curves in MLN-15 showed a biphasic character. It suggested a possibility that $\mathrm{MMC}$ concentration in practically effective form might be reduced within the first half or $1 \mathrm{hr}$ at $37^{\circ} \mathrm{C}$ by binding of MMC with one or some of components contained in MLN-15 but not in MLN-0. Heterogeneity of the cells in the sensitivity to MMC would not exist because the curves in MLN-0 showed one-hit type regressions and the cells utilized had been colonially cloned. Within the first half or $1 \mathrm{hr}$ of the MMC treatment incubation at $37^{\circ} \mathrm{C}$, almost all the free MMC molecules might probably bind with a serum fraction or fractions, when the relative amount of serum to that of MMC was adequately large. Thus the probably serum-bound type of MMC might be much less, but still, effective on the cell killing.

Acknowledgement. Authors wish to appreciate Professor T. Sugahara, M.D., the Dean of the Faculty of Medicine and the Chairman of the Department of Experimental Radiology, Faculty of Medicine, Kyoto University, Kyoto, for his academic encouragement in performing the present research.

The present research was supported in part by the Grant-in-Aid from Science and Technology Agency.

\section{REFERENCES}

1) Kurland, L.T.: An appraisal of the epidemiology and toxicology of alkylmercuy compounds, in Miller, M.W. and Clarkson, T.W. (Eds.) Mercury, Mercurials and Mercaptans, 23-55, Charles C. Thomas Publisher, Springfield, Ill., 1973. 
2) Ramel, C.: Genetic effects of organic mercury compounds (I) Cytological invetigations on allium roots, Hereditas, 61: 208, 1969.

3) Fiskesjoe, G.: The effect of two organic mercury compounds on human leukocytes in vitro. Hereditas, 64: $142,1970$.

4) Oharazawa, H.: Effect of ethyl mercuric phosphate in the pregnat mouse on chromosome abnormalities and fetal malformation, J. Jap. Obstet. Gynecol. Soc., 20: 1479, 1968.

5) Ramel, C. and Magnusson, J.: Genetic effects of organic mercury compounds (II) Chromosome segregation in Drosophila melanogaster, Hereditas, 61: 231, 1969 .

6) Skerfving, S., Hansson, K. and Lindsten, J.: Chromosome breakage in humans exposed to methyl mercury through fish consumption: Preliminary communication, Arch. Environ. Health, $21: 133,1970$

7) Nakazawa, N., Makino, F. and Okada, S.: Acute effects of mercuric compounds on cultured mammalian cells, Biochem. Pharmacol., 24: 489, 1975.

8) Lea, D.E.: Actions of Radiation on Living Cells, 69-99, Cambridge University Press, N.Y. 1962.

\section{和文要旨}

塩化メチル水銀による in vitro 細胞致死の動態をエ 一ルリッヒ腹水腫場細胞を用いて観察し次の所見を得 た.この物質処理による致死の闒値はその処理濃度には 存在するが, その処理時間には存在しない. 非働化成牛 血清は in vitroでェールリッヒ細胞を塩化メチル水銀処 理による致死から防護する．血清による塩化メチル水銀 毒性のみかけ上の低下は, この血清の濃度に依存する が，なお一部毒性が残り完全な防護はできなかった。こ のようにして血清は塩化メチル水銀細胞致死の濃度に拉 ける闘値を上昇せしめた．組織培養系を用いて諸環境内 物質の急性致死作用の動態，ひいてはその作用機作，が ごん速に示唆されらることを確認した.

Reprint requests to Department of Radiation Biology, School of Pharmacy, Kyoto College of Pharmacy, 5, Misasagi Nakauchi-machi, Yamashina-ku, Kyoto, 607 Japan (E. Kano)

著者への通信先 : 加納永一, $=607$ 京都市山科区御陵中内町 5 京都薬科大学生物学教室 